Original Research Paper

\title{
Biodegradation of BTEX: Optimization through Response Surface Methodology
}

\author{
${ }^{1}$ Ayat E. El Telib, ${ }^{2}$ Muftah H. El-Naas and ${ }^{1}$ Janice A. Acio \\ ${ }^{I}$ Department of Chemical and Petroleum Engineering, United Arab Emirates University, Al Ain, UAE \\ ${ }^{2}$ Gas Processing Center, College of Engineering, Qatar University, Doha, Qatar
}

\author{
Article history \\ Received: 06-09-2016 \\ Revised: 21-11-2016 \\ Accepted: 02-01-2017 \\ Corresponding Author: \\ Muftah H. El-Naas \\ Gas Processing Center, College \\ of Engineering, Qatar \\ University, Doha, Qatar \\ Email:Muftah@qu.edu.qa
}

\begin{abstract}
Response Surface Methodology (RSM) was used to optimize the biodegradation of Benzene, Toluene, Ethyl benzene and m-, o-, p-Xylene (BTEX) by Pseudomonas putida immobilized in PVA matrices in a speciallydesigned novel Spouted Bed Bioreactor System (SBBS). A mixture of $60 \mathrm{mg}$ $\mathrm{L}^{-1}$ of BTEX compounds in air was contacted with the immobilized bacteria in three spouted bed bioreactors in series. The parameters investigated include the contaminated air flow rate, operating temperature, PVA volume and water $\mathrm{pH}$. Maximum biodegradation efficiency was predicted to occur at an air flow rate of $500 \mathrm{~mL} \mathrm{~min}{ }^{-1}$, an operating temperature of $33^{\circ} \mathrm{C}$, a PVA volume fraction of $30 \%$ and a $\mathrm{pH}$ of 8.3 . Among the evaluated variables, air flow rate had the most significant effect on the efficiency of BTEX biodegradation. At optimum conditions, the novel bioreactor system was able to achieve maximum removal efficiency of 94, 98, 95 and 98\% for Benzene, Toluene, Ethylbenzene and Xylene, respectively.
\end{abstract}

Keywords: Biodegradation, BTEX, Response Surface Methodology, Spouted Bed Bioreactor, Pseudomonas putida

\section{Introduction}

Benzene, Toluene, Ethylbenzene and Xylene, often referred to as BTEX, are hazardous air pollutants that are commonly found in most industrial gas emissions. Recently, control of these Volatile Organic Compounds (VOC) has become a major concern in air pollution prevention (Tokumura et al., 2008). BTEX compounds are usually found in the vapors or emissions of several sources such as vehicle exhaust, gasoline evaporation, natural gas and liquefied petrochemical gas (Hung-Lung et al., 2007), as well as waste incinerators and composting facilities (Yassaa et al., 2006). They are also emitted through various oil and gas processing activities, such as flaring, venting as well as the dehydration and sweetening of natural gas. Other activities such as exploration, production, refining, storage and transportation of petroleum products may also result in the frequent occurrence of these harmful compounds in air, water and soil (Atlas, 1995).

BTEX are classified as priority pollutants by the U.S. Environmental Protection Agency (EPA), because of their acute toxicity and genotoxicity (Otenio et al., 2005), (CAAALHAP, 2012). They represent a major health hazard to humans and can have detrimental effects on the environment, due to their toxic and cancercausing properties. Even at low ranges of concentrations, BTEX compounds can cause major harm to human organs such as the liver and kidney and may disable the central nervous system (Jo et al., 2008). The Agency for Toxic Substances and Disease Registry published the names of 11 of these compounds in the top 100 chemicals on the "List of Hazardous Substances" (ATSDR, 2013). In order to follow strict regulations and air quality standards, industrial plants need to reduce the concentrations of VOCs gaseous effluents prior to their release into the atmosphere (Mathur et al., 2007). Therefore, it is essential to treat BTEX compounds in air and prevent deterioration of the ecosystem.

Numerous methods for BTEX removal have been evaluated, including conventional techniques such as adsorption, incineration, absorption, thermal and catalytic oxidation (Kennes and Thalasso, 1998). Compared with physical and chemical methods, biological treatment is becoming more popular since it offers a cost effective alternative and it is usually positively perceived by the general public as environmental friendly (Cox and Deshusses, 1998; Robledo-Ortíz et al., 2011). The principle of biodegradation involves contacting the contaminated air 
stream with a bacterial culture that has the ability to utilize the organic pollutant, especially complex hydrocarbons such as BTEX, as a main source of carbon and energy. Successful applications of bioreactors have been mostly found in air pollution control, especially in the treatment of contaminated gas streams for the removal of Volatile Organic Compounds (VOCs) as well as odor control. The volatile or gaseous pollutants can be degraded completely into innocuous or less harmful products such as carbon dioxide and water (Cox and Deshusses, 2002). According to Burgess et al. (2001), the transformation process can be expressed simply by:

$$
\text { Odorous gas }+ \text { oxygen } \rightarrow \text { via bacteria } \rightarrow \text { bacterial }
$$$$
\text { cells }+ \text { carbon dioxide }+ \text { water }
$$

Determining the effectiveness of biotreatment and the availability of microorganisms for degradation of these VOCs have received considerable attention. In recent years many environmental microorganisms can metabolize BTEX and their biodegradative elimination has been heavily developed over the years (Attaway and Schidt, 2002). In this study, a more efficient biodegradation process has been assessed. Bacterial cells, Pseudomonas putida, were immobilized in Polyvinyl Alcohol (PVA) pellets and utilized for the biodegradation of BTEX in a spouted bed bioreactor system. As anon-pathogenic bacteria with a saprophytic lifestyle, Pseudomonas putida are known to have remarkable metabolic versatility (Krell et al., 2012). $P$. putida is perhaps the best characterized aromatic hydrocarbon-degrading bacteria that can use BTEX and other aromatics as sole source of carbon and energy (Reardon et al., 2000). A large number of studies evaluated the effectiveness of $P$. putida for the degradation of BTEX (Shim and Yang, 1999; Robledo-Ortíz et al., 2011; Krell et al., 2012). Moreover, immobilization of the $P$. putida in PVA matrices protects the bacteria from high substrate concentrations and allows ease of separation and reutilization of the biomass (El-Naas et al., 2009). A laboratory scale Spouted Bed Bioreactor System (SBBS) was specially built for the study. The Spouted Bed Bioreactor provides intense cyclic mixing due to the single air jet injected at the bottom of the reactor (El-Naas et al., 2010a).

Since the biodegradation of BTEX by microorganisms is strongly affected by many parameters, it is important to determine the key factors that can significant effect on the degradation process. Common experimental approaches such as "one-factorat-a-time" are often incapable of determining optimum conditions and cannot detect any synergistic effects or interactions between two or more experimental parameters. Thus, through the use Response Surface Method (RSM), one can optimize all the major parameters and eliminate the limitations of one- parameter optimization (Choudhury and El-Baradie, 1999). RSM has been used in various fields such as machining techniques (Choudhury and El-Baradie, 1999), chemical reactions (Sultania et al., 2011; Setiabudi et al., 2013) enzyme and catalytic reactions (Hosseinpour et al., 2011; Thouchprasitchai et al., 2011; Yüksel and Yeşilçubuk, 2012) and with recent broader application extended to the optimization of water and water treatment processes (Güven et al., 2008; Körbahti and Tanyolaç, 2008; Trinh and Kang, 2011; Kumar and Pal, 2012; Yuliwati et al., 2012), in biochemistry (Wang et al., 2012) toxicology studies (Carter et al., 1985; Kiran and Thanasekaran, 2011; Jeong et al., 2012) and in biotechnology for studying biodegradation of phenol (Sheeja and Murugesan, 2002). However, a limited number of studies (Jo et al., 2008; Jin et al., 2013) were reported on the optimization of BTEX's removal efficiency. Therefore, the prime objective of this study is to employ RSM to determine and optimize the key parameters that effect the biodegradation of BTEX in a Spouted Bed Bioreactor System (SBBS) specially-designed for the study.

\section{Materials and Methodology}

\section{Extraction and Immobilization of Bacterial Culture}

The bacteria were obtained in a cereal form (Cleveland Biotech, UK), which contained a consortium of microorganisms, with $P$. putida as the dominate strain. Bacterial cells were extracted from the cereal through two consecutive steps of centrifugation using IEC CL31R Multispeed Centrifuge, Thermo Electron Cooperation, USA. The extracted bacterial cells were collected in a glass jar and stored in a refrigerator for the next step, which is the immobilization in PVA gel pellets. More details about the bacterial extraction and immobilization were reported in a previous publication (El-Naas et al., 2010b).

\section{Biomass Acclimatization}

The immobilized bacteria were slowly acclimatized to Toluene over a period of 5 days by placing them in a nutrient mineral solution with $300 \mathrm{mg} \mathrm{L}^{-1}$ of glucose as an easily biodegrade source of carbon. The concentration of glucose was gradually reduced to zero, while the toluene concentration was gradually increased to $300 \mathrm{mg} \mathrm{L}^{-1}$. At this stage, the bacteria were considered fully acclimatized to toluene as a representative of the BTEX compounds. A similar procedure was reported for the acclimatization of the same biomass to phenol (El-Naas et al., 2010b).

\section{Spouted Bed Bioreactor System (SBBS)}

The patent-pending SBBS consisted of three one-liter spouted bed bioreactors that were made of Plexiglas and equipped with surrounding jackets for temperature 
control. At the start of the experiment, each one of the three reactors was filled with the standard nutrient media solution, in addition to the PVA gel cubes with the immobilized bacteria, which occupied $30 \%$ of the reactor volume (El-Naas et al., 2010a). The three bioreactors were operated in series; the gas leaving from the top of the first reactor was injected into the bottom of the second reactor and then from the second to the third reactor. The good mixing inside the bioreactor provided good contact between the substrate and the bacterial cells which led to good pollutant removal. Mass flow meters (Sierra SideTank) and controller (Auto-Tank) were used for accurate measurement and control of the gas flow rates (BTEX in Air). The standard output for the transducers was $0-5 \mathrm{~V}$, corresponding to a gas flow rate of 0 to $5000 \mathrm{~mL} \mathrm{~min}$. The feed gas mixture contained $10 \mathrm{mg} \mathrm{L}^{-1}$ of each BTEX compound in air and was injected into the bottom of the bed for good mixing and to provide the oxygen needed for the biodegradation.

\section{Analytical Method}

The treated air stream, leaving the reactor, was analyzed for BTEX using a Gas Chromatograph (Varian 3800), which was equipped with a flame ionization detector. Gas samples were withdrawn at 7 min time intervals, using an automatic sampling system and the separation was carried out on a CP-sil $8 \mathrm{CB} 30 \mathrm{~m} \times 0.32 \mathrm{~mm}$ ID, $1 \mu \mathrm{m}$ film thickness fused silica capillary column with Helium as carrier at 18 psi. The column temperature was programmed at a heating rate of $40^{\circ} \mathrm{C} \mathrm{min}-1$ for $1 \mathrm{~min}$, then $35^{\circ} \mathrm{C} \mathrm{min} \mathrm{min}^{-1}$ up to $90^{\circ} \mathrm{C}$; it is held for $1 \mathrm{~min}$ and then raised to $114^{\circ} \mathrm{C}$ at $8^{\circ} \mathrm{C} \mathrm{min}^{-1}$. The temperatures of the injector and detector were maintained constant at $200^{\circ} \mathrm{C}$ and $250^{\circ} \mathrm{C}$, respectively.

Sierra Side-Tank ${ }^{\mathrm{TM}}$ and Auto-Tank $^{\mathrm{TM}}$ mass flow meters and controllers were used for accurately measuring and controlling gas flow rates. Standard output for the transducers was 0-5 V DC signal, which

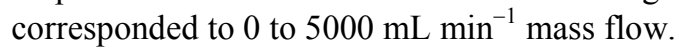

\section{Response Surface Methodology}

Response Surface Methodology (RSM) is a statistical approach that is implemented to determine the relationship between a certain response and a group of factors, which are of importance and interest to the investigator. A model is built to describe the response over specific ranges of the factors of interest. The response surface is referred to as the fitted model in many industrial applications, because the response can then be graphed as a line (curve) for one factor of interest or a surface for two factors of interest
(Mason et al., 2003; Jo et al., 2008). RSM is often used to identify the range of operating conditions that generate the optimum response and satisfy certain operating or process specifications. It may also be used to identify new operating conditions that would improve product quality, while correlating between the response and the main quantitative factors (Cutright and Meza, 2007).

To evaluate the contribution of the solubility of BTEX in water and the role of biodegradation, blank runs were carried out using Toluene as representative of BTEX compounds. Toluene removal (without bacteria) was tested for two reactors in series as shown in Fig. 1. After $50 \mathrm{~min}$, only $15 \%$ of the Toluene was removed by the water as compared to the system with the immobilized bacteria, which achieved $65 \%$ removal. Clearly, the difference in the percentage removal between the two cases is due to the biodegradation of Toluene by the immobilized bacteria. It is important to note here that at the beginning of the experiment, the solubility of toluene in water contributes to the reduction of Toluene until the water in the reactor reaches the saturation limit. Figure 1 also shows the biodegradation efficiency for one, two and three bioreactors in series. The results indicated that the biodegradation of Toluene increasing by about $25 \%$ with the addition of each reactor. However, any improvement in the biodegradation rate beyond the third reactor was not worth the addition of an extra reactor and therefore, only three bioreactors in series were used.

A few experiments were carried to screen out the operating parameters and determine the optimal range of operation. One factor-at-a-time was employed in the screening step to determine the significant factors affecting BTEX degradation (El Telib, 2014). One factor-at-a time implies that only one factor is varied while keeping others constant (Mohapatra et al., 2011).

When the ranges of the optimum values were determined, a full Central Composite Design (CCD) was utilized to find the optimum conditions of the four factors $\left(\mathrm{X}_{1}, \mathrm{X}_{2}, \mathrm{X}_{3}\right.$ and $\left.\mathrm{X}_{4}\right)$. In this study, a total of 31 experiments were conducted in a randomized order as required in many design procedures and 7 center points, giving six degrees of freedom for estimating errors in the experiments (Jo et al., 2008) and verifying any change in the estimation procedure as a measure of the precision property (Mohan et al., 2012). Seven axial points and 17 points equivalent to a matrix of 24 which incorporate 17 experiments $(+1,0,-1)$ including four variables were carried out. It is worth mentioning here that 4 more points' equivalents to a matrix of 24 were added in order to cover the optimal domain for the flow rate. Table 1 shows the levels and codes of each factor as well as the values of experimental designs. 
Table 1. Range and level of independent variables for biodegradation of BTEX

\begin{tabular}{|c|c|c|c|c|c|c|}
\hline \multirow[b]{2}{*}{ Independent variable } & \multirow[b]{2}{*}{ Symbol } & \multicolumn{5}{|c|}{ Level } \\
\hline & & $-\alpha$ & -1 & 0 & +1 & $+\alpha$ \\
\hline Temperature $\left({ }^{\circ} \mathrm{C}\right)$ & $\mathrm{X}_{1}$ & 27.5 & 30 & 32.5 & 35 & 37.5 \\
\hline Flow rate $(\mathrm{ml} / \mathrm{min})$ & $\mathrm{X}_{2}$ & 500 & 700 & 850 & 1000 & 1150 \\
\hline PVA volume (\%) & $X_{3}$ & 15 & 20 & 25 & 30 & 35 \\
\hline $\mathrm{pH}$ & $\mathrm{X}_{4}$ & 5 & 6 & 7 & 8 & 9 \\
\hline
\end{tabular}

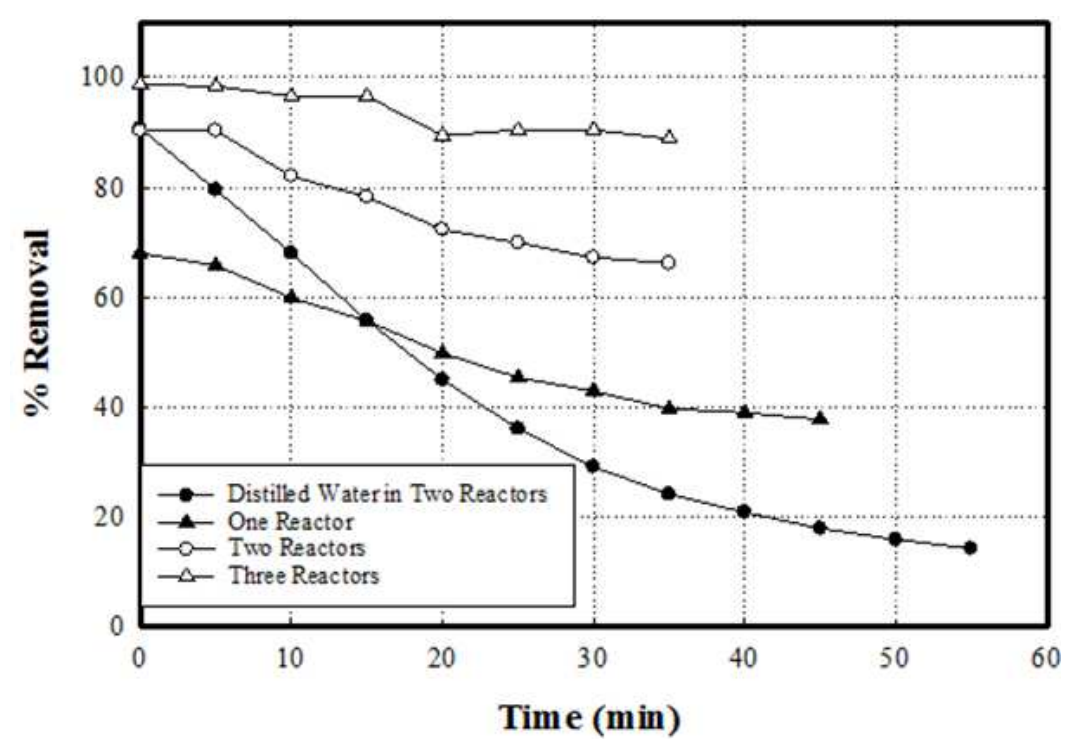

Fig. 1. Biodegradation of toluene at $\mathrm{T}=30^{\circ} \mathrm{C}$; initial toluene concentration $=50 \mathrm{mg} \mathrm{L}$; air flow rate $=500 \mathrm{~mL} \mathrm{~min}^{-1}$

After running the CCD experiments, the response is then represented by the following second-degree quadratic polynomial:

$$
Y=\beta_{0}+\sum_{i=1} \beta_{i} X_{i}+\sum \beta_{i i} X_{i}^{2}+\sum_{i=1} \sum_{j=i+1} \beta_{i j} X_{i} X_{j}
$$

where, $Y$ is the predicted response, $\beta_{o}$ the offset term, $\beta_{i}$ the coefficient of the linear effect, $\beta_{i i}$ the coefficient of squared effect, $X_{i}$ is the coded value of variable $i, X_{j}$ is the coded value of variable $j$ and $\beta_{i j}$ is the coefficient of interaction effect. Temperature, gas flow rate, $\mathrm{pH}$ and PVA volume fraction were chosen as the factors for this study, while the BETX removals were considered as the response variables. Analysis of Variance (ANOVA) was conducted to determine the effects of the three main variables $\left(\mathrm{X}_{1}, \mathrm{X}_{2}, \mathrm{X}_{3}\right.$ and $\left.\mathrm{X}_{4}\right)$ and their interaction on the biodegradation of BTEX as well as the significance of the model and regression coefficients. The feature of polynomial equation was evaluated by determination coefficient $\left(\mathrm{R}^{2}\right)$ and P-value of the lack-of-Fit. The statistical adequacy was evaluated by Fischer's F-test and the significance of regression coefficient was assessed by t-test. Calculations and analysis were carried out using MINITAB Statistical software (Version 16.2, Hewlett-Packard, US).

\section{Results and Discussion}

Optimization of Degradation Conditions using RSM

The experimental results utilized CCD for studying the effect of temperature $\left(\mathrm{X}_{1}\right)$, gas flow rate $\left(\mathrm{X}_{2}\right)$, PVA volume fraction $\% \quad\left(\mathrm{X}_{3}\right)$ and $\mathrm{pH} \quad\left(\mathrm{X}_{4}\right)$ on the biodegradation of each BTEX compound. The experimental results and theoretically predicted responses are presented in Table 2. The experimental results were then analyzed to find an empirical model for the best response. From the analysis of variance for each response, regression equations were obtained, which were then used to explain the mathematical relationship between the factors and responses. These equations are given below in terms of coded factors with all terms regardless of their significance. Using response optimizer, the optimum BTEX removal was found to be at a temperature of $33^{\circ} \mathrm{C}$; a flow rate of $500 \mathrm{ml} / \mathrm{min}$; a PVA volume fraction of $30 \%$ and a $\mathrm{pH}$ of 8.3 .

$$
\begin{aligned}
& Y_{B}=82.95-1.79 X_{1}-5.97 X_{2}+0.30 X_{3}-0.75 X_{4} \\
& -1.09 X_{1}^{2}-0.45 X_{2}^{2}-1.06 X_{3}^{2}-0.19 X_{4}^{2} \\
& -0.44 X_{1} X_{2}-0.39 X_{1} X_{3}-0.02 X_{1} X_{4} \\
& -0.58 X_{2} X_{3}+0.8 X_{2} X_{4}+0.98 X_{3} X_{4}
\end{aligned}
$$




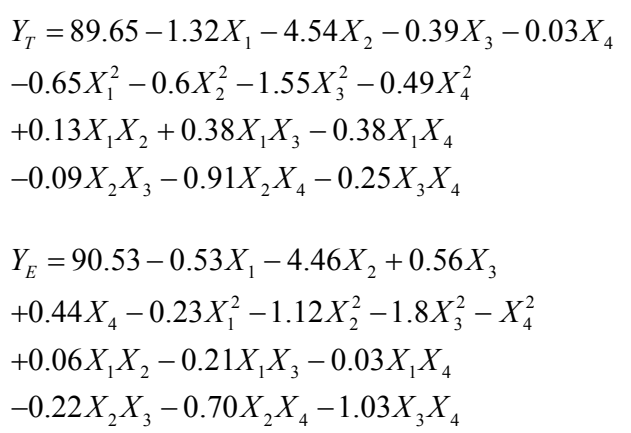

$$
\begin{aligned}
& Y_{m-p X}=92.02-0.07 X_{1}-3.38 X_{2}-0.2 X_{3} \\
& +0.3 X_{4}-0.65 X_{1}^{2}-0.91 X_{2}^{2}-1.1 X_{3}^{2} \\
& -0.35 X_{4}^{2}-0.16 X_{1} X_{2}+0.34 X_{1} X_{3} \\
& -0.04 X_{1} X_{4}-0.5 X_{2} X_{3}-0.94 X_{2} X_{4}-0.54 X_{3} X_{4} \\
& Y_{O-X}=91.88-0.001 X_{1}-2.91 X_{2}-0.08 X_{3} \\
& +0.33 X_{4}-0.15 X_{1}^{2}-0.4 X_{2}^{2}-1.61 X_{3}^{2}-0.09 X_{4}^{2} \\
& -0.22 X_{1} X_{2}+0.18 X_{1} X_{3}+0.18 X_{1} X_{4} \\
& -0.17 X_{2} X_{3}-0.92 X_{2} X_{4}-0.57 X_{3} X_{4}
\end{aligned}
$$

\begin{tabular}{|c|c|c|c|c|c|c|c|c|c|c|c|c|c|c|}
\hline \multirow{2}{*}{$\begin{array}{l}\text { Run } \\
\text { Order }\end{array}$} & \multirow[b]{2}{*}{ Temp } & \multirow[b]{2}{*}{ Flow } & \multirow[b]{2}{*}{ PVA } & \multirow[b]{2}{*}{$\mathrm{pH}$} & \multicolumn{5}{|c|}{ Experimental value \% } & \multicolumn{5}{|c|}{ Predicted value \% } \\
\hline & & & & & $\mathrm{B}$ & $\mathrm{T}$ & $\mathrm{E}$ & $\mathrm{m}-\mathrm{pX}$ & $\mathrm{O}-\mathrm{X}$ & $\mathrm{B}$ & $\mathrm{T}$ & $\mathrm{E}$ & $\mathrm{m}-\mathrm{pX}$ & $\mathrm{O}-\mathrm{X}$ \\
\hline 1 & 32.5 & 850 & 25 & 7 & 83 & 92 & 95 & 96 & 96 & 83 & 89 & 90 & 92 & 92 \\
\hline 2 & 32.5 & 1150 & 25 & 7 & 68 & 78 & 77 & 80 & 84 & 69 & 78 & 77 & 81 & 84 \\
\hline 3 & 30 & 700 & 20 & 8 & 81 & 94 & 95 & 96 & 96 & 83 & 94 & 92 & 94 & 93 \\
\hline 4 & 32.5 & 850 & 25 & 7 & 77 & 91 & 94 & 97 & 95 & 83 & 89 & 90 & 92 & 92 \\
\hline 5 & 32.5 & 850 & 35 & 7 & 77 & 78 & 84 & 86 & 85 & 80 & 84 & 85 & 88 & 86 \\
\hline 6 & 32.5 & 850 & 25 & 7 & 85 & 91 & 93 & 95 & 94 & 83 & 89 & 90 & 92 & 92 \\
\hline 7 & 35 & 1000 & 30 & 6 & 72 & 84 & 84 & 87 & 88 & 70 & 81 & 83 & 86 & 87 \\
\hline 8 & 35 & 700 & 20 & 8 & 81 & 90 & 93 & 93 & 96 & 82 & 90 & 91 & 93 & 94 \\
\hline 9 & 37.5 & 850 & 25 & 7 & 69 & 82 & 87 & 90 & 90 & 75 & 84 & 89 & 89 & 91 \\
\hline 10 & 32.5 & 850 & 15 & 7 & 80 & 88 & 80 & 89 & 82 & 78 & 85 & 83 & 88 & 86 \\
\hline 11 & 30 & 700 & 20 & 6 & 86 & 90 & 88 & 91 & 93 & 88 & 91 & 88 & 91 & 90 \\
\hline 12 & 32.5 & 850 & 25 & 7 & 81 & 84 & 87 & 89 & 91 & 83 & 89 & 90 & 92 & 92 \\
\hline 13 & 32.5 & 850 & 25 & 7 & 86 & 90 & 89 & 91 & 93 & 83 & 89 & 90 & 92 & 92 \\
\hline 14 & 32.5 & 550 & 25 & 7 & 90 & 92 & 93 & 92 & 94 & 93 & 96 & 94 & 96 & 95 \\
\hline 15 & 35 & 1000 & 20 & 6 & 75 & 81 & 78 & 84 & 87 & 74 & 82 & 80 & 86 & 87 \\
\hline 16 & 35 & 1000 & 20 & 8 & 72 & 78 & 84 & 87 & 88 & 71 & 79 & 81 & 86 & 87 \\
\hline 17 & 30 & 1000 & 30 & 8 & 76 & 82 & 82 & 85 & 86 & 77 & 82 & 81 & 83 & 85 \\
\hline 18 & 30 & 1000 & 20 & 8 & 73 & 81 & 82 & 85 & 87 & 75 & 84 & 84 & 87 & 88 \\
\hline 19 & 32.5 & 850 & 25 & 9 & 82 & 89 & 85 & 90 & 91 & 81 & 88 & 87 & 91 & 92 \\
\hline 20 & 32.5 & 850 & 25 & 7 & 84 & 89 & 88 & 90 & 87 & 83 & 89 & 90 & 92 & 92 \\
\hline 21 & 32.5 & 850 & 25 & 7 & 84 & 92 & 87 & 89 & 86 & 83 & 89 & 90 & 92 & 92 \\
\hline 22 & 30 & 700 & 30 & 6 & 90 & 92 & 91 & 92 & 92 & 89 & 90 & 91 & 92 & 92 \\
\hline 23 & 30 & 1000 & 20 & 6 & 76 & 84 & 84 & 87 & 89 & 78 & 85 & 83 & 87 & 88 \\
\hline 24 & 32.5 & 850 & 25 & 5 & 82 & 86 & 86 & 91 & 89 & 84 & 88 & 86 & 90 & 91 \\
\hline 25 & 30 & 1000 & 30 & 6 & 75 & 84 & 83 & 85 & 88 & 75 & 83 & 84 & 85 & 88 \\
\hline 26 & 35 & 1000 & 30 & 8 & 76 & 81 & 81 & 83 & 85 & 73 & 79 & 80 & 83 & 85 \\
\hline 27 & 27.5 & 850 & 25 & 7 & 88 & 91 & 90 & 88 & 89 & 82 & 90 & 91 & 89 & 91 \\
\hline 28 & 35 & 700 & 20 & 6 & 88 & 89 & 89 & 90 & 91 & 86 & 89 & 87 & 91 & 90 \\
\hline 29 & 35 & 700 & 30 & 6 & 89 & 91 & 92 & 92 & 93 & 86 & 90 & 92 & 94 & 93 \\
\hline 30 & 30 & 700 & 30 & 8 & 87 & 93 & 94 & 94 & 94 & 89 & 93 & 92 & 93 & 93 \\
\hline 31 & 32.5 & 850 & 20 & 7 & 85 & 89 & 89 & 90 & 92 & 81 & 89 & 88 & 91 & 90 \\
\hline 32 & 32.5 & 500 & 25 & 7 & 95 & 97 & 95 & 96 & 95 & 92 & 99 & 96 & 97 & 97 \\
\hline 33 & 32.5 & 500 & 25 & 8 & 94 & 98 & 95 & 98 & 98 & 93 & 96 & 95 & 95 & 96 \\
\hline 34 & 35.0 & 500 & 25 & 7 & 94 & 98 & 94 & 98 & 98 & 95 & 96 & 95 & 96 & 95 \\
\hline 35 & 32.5 & 500 & 30 & 7 & 94 & 96 & 95 & 97 & 96 & 94 & 95 & 93 & 96 & 95 \\
\hline
\end{tabular}

Table 2. Full Factorial central composite design (CCD) for BTEX removal

Table 3. ANOVA of quadratic model for Benzene

\begin{tabular}{llllll}
\hline Source & Sum of squares & Degrees of freedom & Mean square & F-value & P-value \\
\hline Model & 1614.98 & 14 & 115.36 & 10.15 & 0.000 \\
Residual & 227.30 & 20 & 12.415 & 14.2 & 0.375 \\
Lack of fit & 172.45 & 14 & 9.143 & & \\
Pure error & 54.86 & 6 & & & \\
Total & 1842.29 & 34 & & & \\
\hline
\end{tabular}

\footnotetext{
$*$ Std dev $=3.37$, Mean $=82.95$
} 
Table 4. ANOVA of quadratic model for Toluene

\begin{tabular}{llllll}
\hline Source & Sum of squares & Degrees of freedom & Mean square & F-value & P-value \\
\hline Model & 958.35 & 14 & 68.454 & 9.13 & 0.00 \\
Residual & 149.93 & 20 & 7.687 & & 0.98 \\
Lack of fit & 103.07 & 14 & 7.62 & 0.542 \\
Pure error & 46.86 & 6 & 7.81 & & \\
Total & 1108.29 & 34 & & & \\
\hline
\end{tabular}

$*$ Std dev $=2.74$, Mean $=89.65$

Table 5. ANOVA of quadratic model for Ethylbenzene

\begin{tabular}{llllll}
\hline Source & Sum of squares & Degrees of freedom & Mean square & F-value & P-value \\
\hline Model & 844.416 & 14 & 60.315 & 9.55 & 0.000 \\
Residual & 126.327 & 20 & 6.316 & & 0.33 \\
Lack of fit & 54.612 & 14 & 3.901 & 0.960 \\
Pure error & 71.714 & 6 & 11.952 & & \\
Total & 970.743 & 34 & & & \\
\hline
\end{tabular}

$*$ Std dev $=2.51$, Mean $=90.53$

Table 6. ANOVA of quadratic model for m-pXylene

\begin{tabular}{llllll}
\hline Source & Sum of squares & Degrees of freedom & Mean square & F-value & P-value \\
\hline Model & 582.034 & 14 & 41.574 & 6.81 & 0.000 \\
Residual & 122.138 & 20 & 6.107 & & 0.3 \\
Lack of fit & 50.423 & 14 & 3.602 & & 0.970 \\
Pure error & 71.714 & 6 & 11.952 & & \\
Total & 704.171 & 34 & & & \\
\hline
\end{tabular}

*Std dev $=2.47$, Mean $=92.02$

Table 7. ANOVA of quadratic model for o-Xylene

\begin{tabular}{llllll}
\hline Source & Sum of squares & Degrees of freedom & Mean square & F-value & P-value \\
\hline Model & 461.975 & 14 & 32.998 & 4.47 & 0.001 \\
Residual & 147.625 & 20 & 7.381 & & 0.26 \\
Lack of fit & 56.196 & 14 & 4.014 & 0.981 \\
Pure error & 91.429 & 6 & 15.238 & & \\
Total & 609.600 & 34 & & & \\
\hline
\end{tabular}

$*$ Std dev $=2.72$, Mean $=91.88$

\section{Analysis of Variance (ANOVA)}

The results of Analysis of Variance (ANOVA) are shown in Table 3-7 and indicate that the model can predict the experimental data within the $95 \%$ confidence interval. From a statistical point view, the $\mathrm{p}$-value is a good indicator of the statistical significance and adequacy of the model can be inferred from the p-value of the lack-of-fit. If this value is greater than 0.05 , there is no statistical significance of the lack-of-fit at the $95 \%$ confidence level and the model is considered adequate. The pvalues of the lack-of-fit for the results, as shown in Table $3-7$, are clearly more than 0.05 , which confirms that the model is adequate.

\section{Effect of Temperature}

Figure 2 represents the maximum Benzene removal selected here as an example of the BTEX and plotted against temperature $\left(\mathrm{X}_{1}\right)$ and PVA $\left(\mathrm{X}_{3}\right)$ while keeping the flow rate $\left(\mathrm{X}_{2}\right)$ and $\mathrm{pH}\left(\mathrm{X}_{4}\right)$ constant. A small increase in Benzene removal \% could be achieved when the value of temperature increased from 32.5 to $35^{\circ} \mathrm{C}$, beyond this the removal $\%$ is decreased. The maximum percentage of Toluene, Ethylbenzene, m-pXylene and o-Xylene degradation was found to occur at $30,37,33,37.5^{\circ} \mathrm{C}$, respectively. The removal $\%$ increased as the temperature increased from 30 to 35 and then decreased. It is believed that sudden exposure to temperature higher than $35^{\circ} \mathrm{C}$ might have detrimental effects on the bacterial enzymes that are often responsible for the main step in the biodegradation process (El-Naas et al., 2009). In addition, low temperature slows down the bacterial activity. The optimum temperature for the maximum specific growth rate of Pseudomonas putida falls between 30 and $35^{\circ} \mathrm{C}$ (Alagappan and Cowan, 2004). This is clearly reflected in the biodegradation rate of Benzene as an example of the BTEX, with $33^{\circ} \mathrm{C}$ as the optimum temperature. Moreover, the operating temperature can have major effects on mass transfer within the reactor, which could influence the reactor performance (Oh et al., 1994).

\section{Effect of Gas Flow rate}

The interactions between the flow rate $\left(\mathrm{X}_{2}\right)$ and temperature $\left(\mathrm{X}_{1}\right)$ were analyzed using $3 \mathrm{D}$ response 
surface plots. Figure 3 clearly shows that biodegradation efficiency of Benzene decreased with increasing the gas flow rate from 500 to $1150 \mathrm{~mL}$ min-. Maximum removal of approximately 94, 98, 95, 98 and 98\% for Benzene, Toluene, Ethylbenzen, m-pXylene and o-Xylene, respectively, were obtained at the lowest flow rate of 500 $\mathrm{ml} / \mathrm{min}$. This is expected since longer gas residence time results in higher biodegradation rate. As the gas bubbles through the liquid in the bioreactor, its solubility in water limits its accessibility to the biomass.

\section{Effect of $p H$}

The initial $\mathrm{pH}$ of the mineral nutrient solution plays a significant role in the microbial growth and enzyme activity and it is often considered to be a key parameter for the development of biological treatment processes (El Hajjouji et al., 2008; Yus Azila et al., 2008). The effects of the initial $\mathrm{pH}$ of the mineral nutrient solution (from 5 to 9) on the BTEX degradation rate were determined and the results are shown in Fig. 4 for Benzene. The initial $\mathrm{pH}$ seemed to have significant effect on the biodegradation of BTEX, which seemed to increase with increasing $\mathrm{pH}$, reaching the maximum at a $\mathrm{pH}$ value of 8 . When the initial $\mathrm{pH}$ in the medium was lower than 6 , the BTEX degradation rate significantly decreased, but declined slightly for $\mathrm{pH}$ values higher than 8 as shown in the figure for Benzene. The maximum percentage of Toluene, Ethylbenzen, m-pXylene and o-Xylene degradation was found to occur with $\mathrm{pH} 9,8,9$ and 9, respectively. However, Benzene has maximum removal $\%$ at $5 \mathrm{pH}$. The physiological effect of $\mathrm{pH}$ on microbial activity is similar to that of temperature, as almost all biological species seem to have optimal $\mathrm{pH}$ conditions. Although some species are more tolerant to a wider $\mathrm{pH}$ range, others prefer a narrow $\mathrm{pH}$ range. Some species are good at high $\mathrm{pH}$ and some at low $\mathrm{pH}$. For the biodegradation of BTEX mixtures by Pseudomonas putida, a study by You et al. (2013) revealed that biomass activity was fully inhibited at $\mathrm{pH}$ 5, 9 and 10 and the optimum was at $\mathrm{pH}$ 6- 8. Most bacteria are neutrophils, so the optimum $\mathrm{pH}$ at which the highest degree of BTEX biodegradation is achieved is usually around 7.5 (Słomińska et al., 2012).

\section{Effect of PVA Volume \%}

Three-dimensional plot representing removal percentage of Benzene degradation against PVA volume fraction (15-35\%) and $\mathrm{pH}(5-9)$ is shown in Fig. 5, while keeping the gas flow rate and temperature constant. The volume fraction of PVA pellets is directly related to the number of active biomass cells in the bioreactor and hence plays an important role in determining the rate of BTEX degradation. The maximum removal efficiency for
Benzene, Toluene, Ethylbenzen, m-pXylene and oXylene were found at PVA volume fraction of 25, 25, 27.5, 26.5 and 26.5\%, respectively. As the PVA volume fraction increases, the \% BTEX removal increases. However, PVA volume fraction 25 and $30 \%$ seem to have almost the same removal efficiency. This may be due to the fact that the $30 \%$ has more biomass, while the $25 \%$ has better mixing. It is expected that increasing the amount of PVA volume fraction beyond $30 \%$ results in less mixing, consequently, lower degradation efficiency.

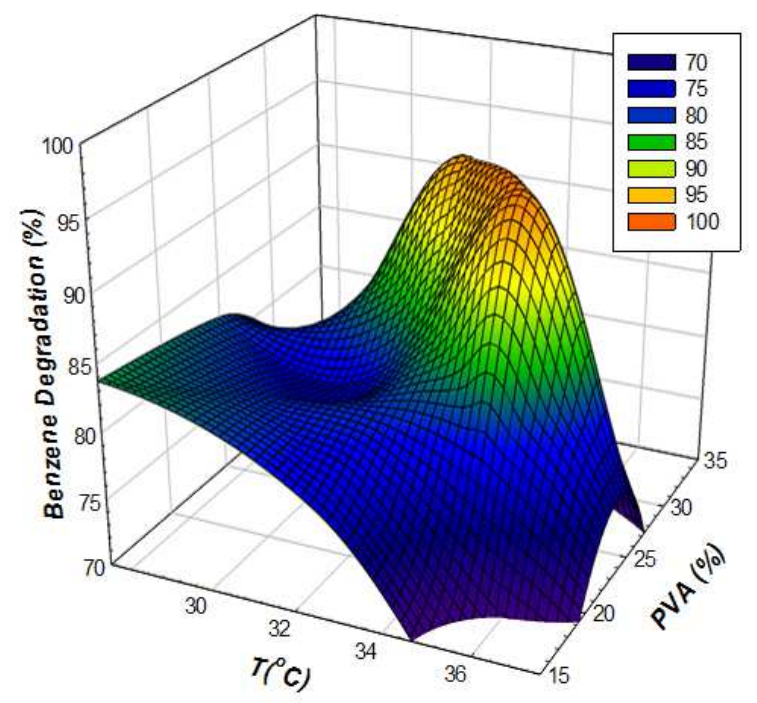

Fig. 2. Surface response optimization of Benzene degradation versus temperature and PVA volume

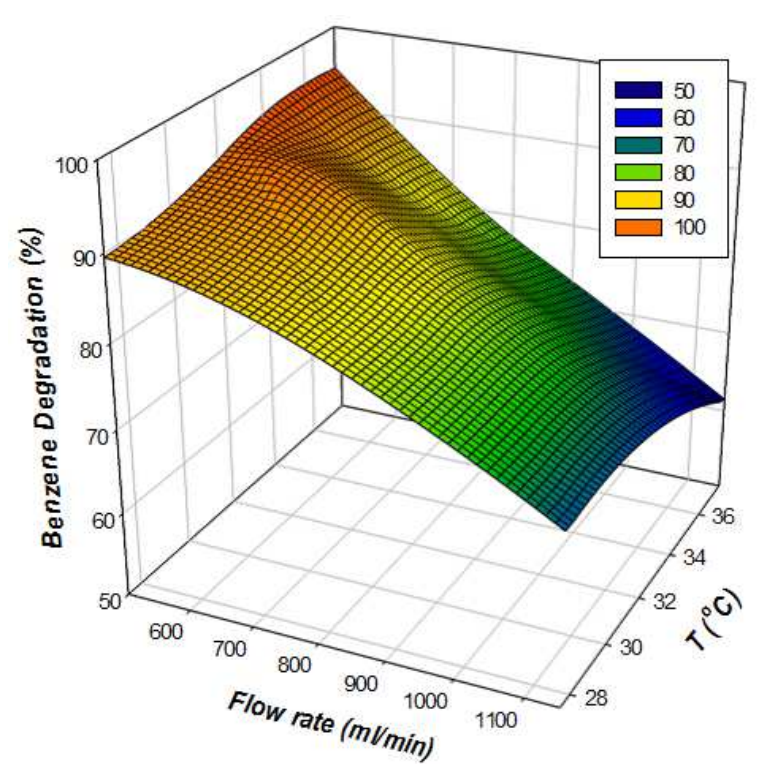

Fig. 3. Surface response optimization of Benzene degradation versus temperature and gas flow rate 


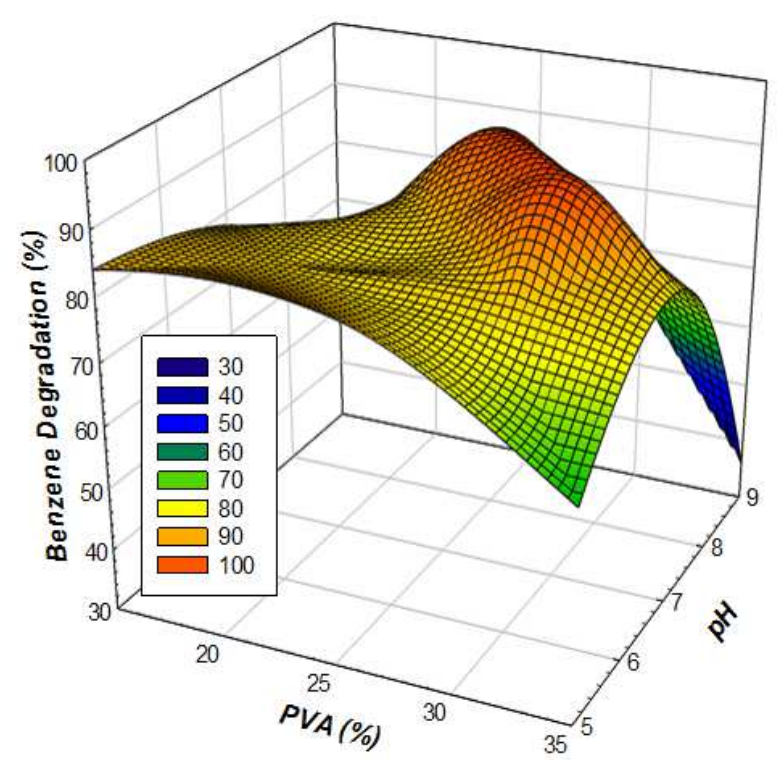

Fig. 4. Surface response optimization of Benzene degradation versus $\mathrm{pH}$ and PVA volume

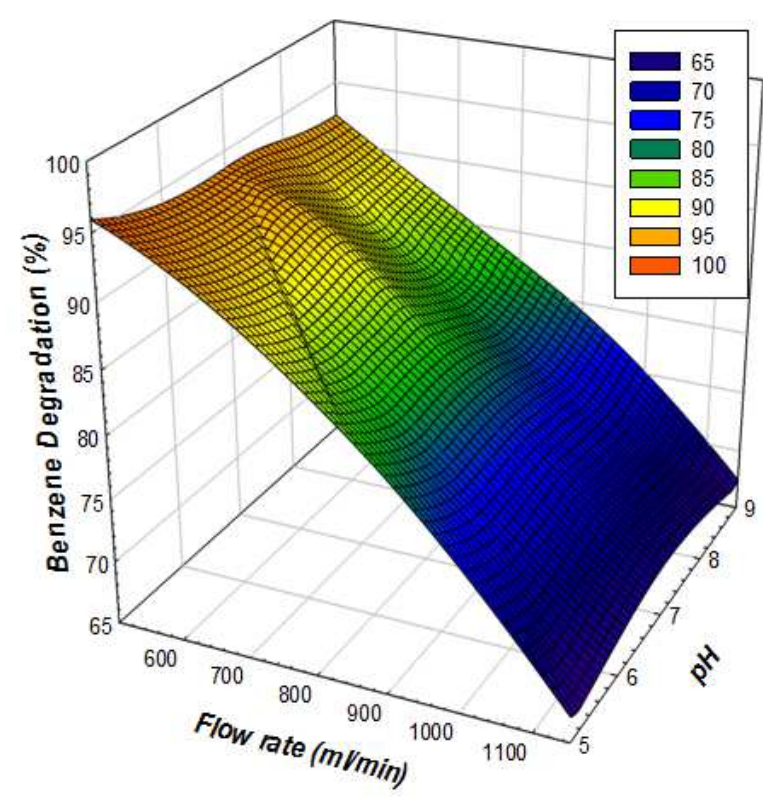

Fig. 5. Surface response optimization of Benzene degradation versus $\mathrm{pH}$ and gas flow rate

\section{Desirability}

Using Response Optimizer, the effect of the presence or absence of an individual compound on the biodegradation rate was predicted. Maximum removals of 94, 98, 95 and 98\% were achieved for Benzene, Toluene, Ethylbenzene and m,p,o-Xylene at the optimal conditions determined by the response surface analysis.
In a mixture of BTEX, the isomers of Xylene were consumed first due to: (i) Different enzymatic systems catabolize the ring fission products of diverse catechols (Duggleby and Williams, 1986) and (ii) Xylene degradation may lead to accumulation and polymerization of intermediates such as toluic acid, tolualdehyde and methyl salicylic acid (Davey and Gibson, 1974; Chang et al., 1993). Without the presence of Benzene, the removal can reach up to $99 \%$, for Toluene, $97 \%$ for Ethylbenzene and $98 \%$ for the Xylenes. The absence of Benzene and Ethylbenzene enhanced the biodegradation of Toluene and Xylenes reaching up to 99 and $98 \%$, respectively. It was observed that the presence of m-pXylene slows down the utilization of Toluene and Benzene which agrees with the findings reported by Oh et al. (1994).

The presence of Ethylbenzene inhibits BTX degradation (Reardon et al., 2000). It was also reported that for the degradation of a binary mixture of Toluene and Benzene, the biomass $P$. putida F1 utilized Toluene better than Benzene. The presence of Toluene was also reported to inhibit the degradation of Benzene (Baggi, 2000; Jo et al., 2008; Song et al., 2012) \{JIHYEON SONG, 2012, Kinetics and simulations of substrate interactions during the biodegradation of benzene', toluene', pxylene and styrene\}. One can therefore predict that the presence of both Benzene and Ethylbenzene in the system inhibits the biodegradation of other compounds. The severe antagonistic effects during the biodegradation of mixtures of BTEX compounds can be caused by competitive inhibition, toxicity and the formation of toxic intermediates by nonspecific enzymes (Jo et al., 2008).

\section{Validation of the model}

Experimental validation is an essential step for confirming the adequacy of the statistical model and this was performed through running experiments at the

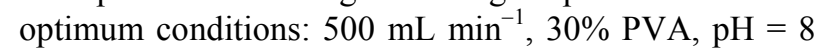
and maintaining the temperature at $33^{\circ} \mathrm{C}$. The predicted and experimental response for Benzene degradation was exactly the same at $94 \%$. For Toluene, Ethyl benzene and Xylenes the experimental value were all 2\% lower than the predicted values at 97, 94 and 95\%, respectively but still within the $95 \%$ Confidence Interval (95\% CI). Therefore, all the experimental values were close to the predicted values. Moreover, response optimizer was used and compared with the experimental results for dual components (Benzene-Toluene). The response optimizer predicted that working with temperature $=$ $32^{\circ} \mathrm{C}$, flow rate $=500 \mathrm{~mL} \mathrm{~min}^{-1}, \mathrm{pH}=8$ and $\mathrm{PVA}=$ $30 \%$ will give $95 \%$ removal for Benzene and $98 \%$ removal for Toluene, which are very close to the experimental results as showing in Fig. 6. 


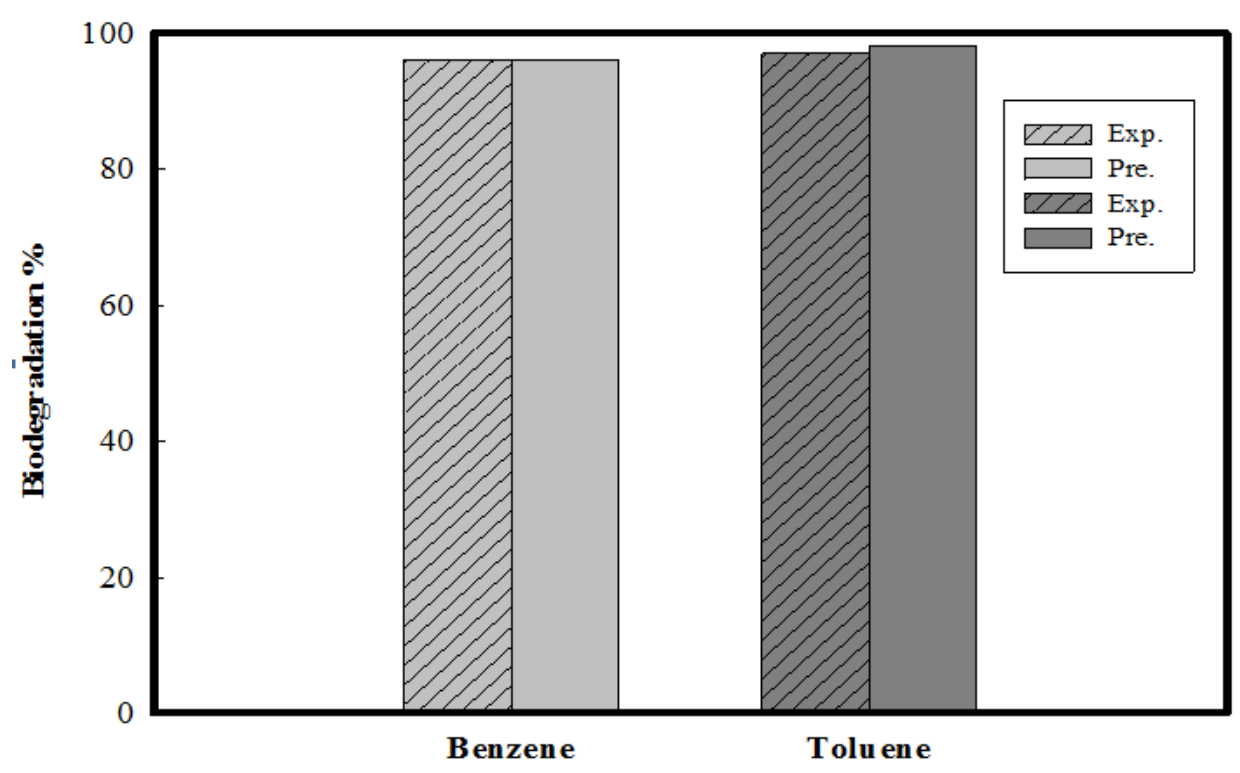

Fig. 6. A comparison of predicted and experimental results for the biodegradation of dual components (Benzene-Toluene) at $\mathrm{T}=$ $32^{\circ} \mathrm{C}$; PVA volume $=30 \%$; air flow rate at $500 \mathrm{~mL} \mathrm{m^{-1 }}$

\section{Conclusion}

The biodegradation of BTEX was evaluated in a special spouted bed bioreactor system and the optimum values for the operating conditions were determined. The study revealed that second order polynomial was adequate in predicting the BTEX degradation within four independent variables: Temperature, gas flow rate, $\mathrm{pH}$ and PVA volume \%. All four variables indicated significant effect on the biodegradation of BTEX and decreasing the gas flow rate played a major role in the removal efficiency. Analysis of Variance (ANOVA) for the biodegradation of BTEX provided a coefficient of determination $\left(\mathrm{R}^{2}\right)$ of $82.2 \%$, which indicated that the model had a good fit. Desirability study revealed that the presence of Benzene and Ethylbenzene decreased the removal of other components. The overall optimum conditions predicted by the response surface model in order to get maximum removal of 94, 98, 95, $98 \%$ for BTEX were: A gas flow rate of $500 \mathrm{~mL}$ $\min ^{-1}$; an operating temperature of $33^{\circ} \mathrm{C}$; a PVA volume fraction of $30 \%$ and a $\mathrm{pH}$ of 8.3 .

\section{Acknowledgement}

The authors gratefully acknowledge the financial support of the National Research Foundation (NRF) of the United Arab Emirates (UAE). Special thanks are also due to Prof. KilaniGhoudi, Statistics Department, UAE University, for his help with the statistical analysis and Eng. Ameera Mohammad for her help with manuscript preparation.

\section{Author's Contributions}

Ayat El Telib: She made considerable contributions including carrying out the experimental work, analyzing and modeling the experimental data. She also prepared the initial draft of the manuscript.

Muftah El-Naas: He made considerable contributions including designing the research plan and experimental procedure. In addition, he supervised the experimental work and revised the draft of the manuscript.

Janice Acio: She helped with carrying out the experimental work and data analysis.

\section{Ethics}

This paper is original and includes unpublished materials. The corresponding author authorizes that all other authors have read and agreed the manuscript and there is no ethical issues involved.

\section{References}

ATSDR, 2013. Agency for toxic substances and disease registry.

Alagappan, G. and R.M. Cowan, 2004. Effect of temperature and dissolved oxygen on the growth kinetics of Pseudomonas putida F1 growing on benzene and toluene. Chemosphere, 54: 0045-6535. DOI: 10.1016/j.chemosphere.2003.09.013

Atlas, R.M., 1995. Bioremediation of petroleum pollutants. Int. Biodeteriorat., 35: 317-327. DOI: 10.1016/0964-8305(95)00030-9 
Attaway, H. and M. Schidt, 2002. Tandem biodegradation of BTEX components by two Pseudomonas sp. Curr. Microbiol., 45: 30-36. DOI: $10.1007 / \mathrm{s} 00284-001-0053-1$

Baggi, G., 2000. Ecological implications of synergistic and antagonistic interactions among growth and non growth analogs present in mixture. Annals Microbiol., 50: 103-115.

Burgess, J.E., S.A. Parsons and R.M. Stuetz, 2001. Developments in odour control and waste gas treatment biotechnology: A review. Biotechnol. Adv., 19: 35-63. DOI: 10.1016/S0734-9750(00)00058-6

Carter, J.R., D.E. Jones and R.A. Carchman, 1985. Application of response surface methods for evaluating the interactions of soman, atropine and pralidioxime chloride. Fundamental Applied Toxicol., 5: S232-S241. DOI: $10.1016 / 0272-0590(85) 90133-2$

Chang, M.K. T.C. Voice and C.S. Criddle, 1993. Kinetics of competitive inhibition and cometabolism in the biodegradation of benzene, toluene and $p$ xylene by two Pseudomonas isolates. Biotechnol. Bioeng., 41: 1057-1065.

DOI: $10.1002 /$ bit.260411108

Choudhury, I.A. and M.A. EL-Baradie, 1999. Machinability assessment of inconel 718 by factorial design of experiment coupled with response surface methodology. J. Mater. Process. Technol., 95: 30-39. DOI: 10.1016/S0924-0136(99)00085-0

Cox, H.H.J. and M.A. Deshusses, 1998. Biological waste air treatment in biotrickling filters. Curr. Opin. Biotechnol., 9: 256-262.

DOI: $10.1016 / \mathrm{s} 0958-1669(98) 80056-6$

Cox, H.H.J. and M.A. Deshusses, 2002. Co-treatment of $\mathrm{H}_{2} \mathrm{~S}$ and toluene in a biotrickling filter. Chem. Eng. J., 87: 101-110. DOI: 10.1016/S1385-8947(01)00222-4

Cutright, T.J. and L. Meza, 2007. Evaluation of the aerobic biodegradation of trichloroethylene via response surface methodology. Environ. Int., 33: 338-345. DOI: 10.1016/j.envint.2006.11.012

Davey, J.F. and D.T. Gibson, 1974. Bacterial metabolism of para- and meta-xylene: Oxidation of a methyl substituent. J. Bacteriol., 119: 923-929. PMID: 4850727

Duggleby, C.J. and P.A. Williams, 1986. Purification and some properties of the 2-hydroxy-6-oxohepta2,4-dienoate hydrolase (2-hydroxymuconic semialdehyde hydrolase) encoded by the TOL plasmid pWW0 from Pseudomonas putida MT-2. J. General Microbiol., 132: 717-726. DOI: $10.1099 / 00221287-132-3-717$

El Hajjouji, H., G. Ait Baddi, A. Yaacoubi, H. Hamdi and P. Winterton et al., 2008. Optimisation of biodegradation conditions for the treatment of olive mill wastewater. Bioresource Technol., 99: 5505-5510. DOI: 10.1016/j.biortech.2007.11.005
El Telib, A., 2014. Optimizationof the Biodegradationof BTEX byPseudomonas Putida Immobilizedin PVA Gel. M.Sc. Thesis, UAE University. Al Ain. UAE.

El-Naas, M.H. S.A. Al-Muhtaseb and S. Makhlouf, 2009. Biodegradation of phenol by Pseudomonas putida immobilized in Polyvinyl Alcohol (PVA) gel. J. Hazardous Mater., 164: 720-725. DOI: 10.1016/j.jhazmat.2008.08.059

El-Naas, M.H. S. Al-Zuhair and S. Makhlouf, 2010a. Batch degradation of phenol in a spouted bed bioreactor system. J. Indust. Eng. Chem., 16: 267-272. DOI: 10.1016/j.jiec.2009.09.072

El-Naas, M.H. S. Al-Zuhair and S. Makhlouf, 2010b. Continuous biodegradation of phenol in a Spouted Bed Bioreactor (SBBR). Chem. Eng. J., 160: 565-570. DOI: $10.1016 /$ j.cej.2010.03.068

Güven, G. A. Perendeci and A. Tanyolaç, 2008. Electrochemical treatment of deproteinated whey wastewater and optimization of treatment conditions with response surface methodology. J. Hazardous Mater., 157: 69-78. DOI: $10.1016 /$ j.jhazmat.2007.12.082

Hosseinpour, V., M. Kazemeini and A. Mohamma Drezaee, 2011. A study of the water-gas shift reaction in Rupromoted Ir-catalysed methanol carbonylation utilising experimental design methodology. Chem. Eng. Sci., 66: 4798-4806. DOI: 10.1016/j.ces.2011.06.053

Hung-Lung, C., T. Jiun-Horng, C. Shih-Yu, L. KuoHsiung and M. Sen-Yi et al., 2006. VOC concentration profiles in an ozone non-attainment area: A case study in an urban and industrial complex metroplex in southern Taiwan. Atmospheric Environ., 41: 1848-1860. DOI: 10.1016/j.atmosenv.2006.10.055

Jeong, I.S., B.M. Kwak, J.H. Ahn and S.H. Jeong, 2012. Determination of pesticide residues in milk using a QuEChERS-based method developed by response surface methodology. Food Chem., 133: 473-481. DOI: 10.1016/j.foodchem.2012.01.004

Jin, H.M., E.J. Choi and C.O. Jeon, 2013. Isolation of a Btex-degrading bacterium, Janibacter sp. SB2, from a sea-tidal flat and optimization of biodegradation conditions. Bioresource Technol., 145: 57-64. DOI: 10.1016/j.biortech.2013.02.004

Jo, M.S., E.R. Rene, S.H. Kim and H.S. Park, 2008. An analysis of synergistic and antagonistic behavior during BTEX removal in batch system using response surface methodology. J. Hazardous Mater., 152: $1276-1284$.

DOI: $10.1016 /$ j.jhazmat.2007.08.002

Kennes, C. and F.D. Thalasso, 1998. Waste gas biotreatment technology. J. Chem. Technol. Biotechnol., 72: 303-319.

DOI: $\quad 10.1002 /(\mathrm{SICI}) 1097-$ 4660(199808)72:4<303::AID-JCTB903>3.0.CO;2-Y 
Kiran, B. and K. Thanasekaran, 2011. Copper biosorption on Lyngbya putealis: Application of response surface methodology (RSM). Int. Biodeteriorat. Biodegradat., 65: 840-845.

DOI: 10.1016/j.ibiod.2011.06.004

Krell, T., J. Lacal, M.E. Guazzaroni, A. Busch and H. Silva-Jiménez et al., 2012. Responses of Pseudomonas putida to toxic aromatic carbon sources. J. Biotechnol., 160: 25-32. DOI: $10.1016 /$ j.jbiotec.2012.01.026

Kumar, R. and P. Pal, 2012. Response surface-optimized Fenton's pre-treatment for chemical precipitation of struvite and recycling of water through downstream nanofiltration. Chem. Eng. J., 210: 33-44. DOI: $10.1016 /$ j.cej.2012.08.036

Körbahti, B.K. and A. Tanyolaç, 2008. Electrochemical treatment of simulated textile wastewater with industrial components and Levafix Blue CA reactive dye: Optimization through response surface methodology. J. Hazardous Mater., 151: 422-431. DOI: 10.1016/j.jhazmat.2007.06.010

Mason, R.L., R.F. Gunst and J.L. Hess, 2003. Statistical Design and Analysis of Experiments: With Applications to Engineering and Science. 1 st Edn., John Wiley and Sons, ISBN-10: 0471458511, pp: 760.

Mathur, A.K. C.B. Majumder and S. Chatterjee, 2007. Combined removal of BTEX in air stream by using mixture of sugar cane bagasse, compost and GAC as biofilter media. J. Hazardous Mater., 148: 64-74. DOI: 10.1016/j.jhazmat.2007.02.030

Mohan, P.R., B. Ramesh and O.V.S. Reddy, 2012. Production and Optimization of Ethanol from Pretreated Sugarcane Bagasse using Saccharomyces bayanus in Simultaneous Saccharification and Fermentation. Microbiol. J., 2: 52-63. DOI: $10.3923 / \mathrm{mj} .2012 .52 .63$

Mohapatra, D.P., S.K. Brar, R.D. Tyagi and R.Y. Surampalli, 2011. Parameter optimization of ferrosonication pre-treatment process for degradation of bisphenol $\mathrm{A}$ and biodegradation from wastewater sludge using response surface model. J. Hazardous Mater., 189: 100-107.

DOI: 10.1016/j.jhazmat.2011.02.004

Oh, Y.S., Z. Shareefdeen, B.C. Baltzis and R. Bartha, 1994. Interactions between Benzene, Toluene and pXylene (BTX) during their biodegradation. Biotechnol. Bioeng., 44: 533-538. DOI: $10.1002 /$ bit.260440417

Otenio, M.H., M.T.L. da Silva, M.L.O. Marques, J.C. Roseiro and E.D. Bidoia, 2005. Benzene, Toluene and Xylene Biodegradation by Pseudomonas Putida CCMI 852. Brazilian J. Microbiol., 36: 258-261.

DOI: $10.1590 / \mathrm{S} 1517-83822005000300010$
Reardon, K.F. D.C. Mosteller and J.D. Bull Rogers, 2000. Biodegradation kinetics of benzene, toluene and phenol as single and mixed substrates for Pseudomonas putida F1. Biotechnol. Bioeng., 69: 385-400. DOI: 10.1002/10970290(20000820)69:4<385::AID-BIT5>3.0.CO;2-Q

Robledo-Ortíz, J.R., D.E. Ramírez-Arreola, A.A. PérezFonseca, C. Gómez and C. Gómez et al., 2011. Benzene, toluene and o-xylene degradation by free and immobilized $P$. putida $\mathrm{F} 1$ of postconsumer agave-fiber/polymer foamed composites. Int. Biodeteriorat. Biodegradat., 65: 539-546.

DOI: 10.1016/j.ibiod.2010.12.011

Setiabudi, H.D., A.A. Jalil, S. Triwahyono, N.H.N. Kamarudin and R. Jusoh, 2013. Ir/Pt-HZSM5 for npentane isomerization: Effect of $\mathrm{Si} / \mathrm{Al}$ ratio and reaction optimization by response surface methodology. Chem. Eng. J., 217: 300-309.

DOI: 10.1016/j.cej.2012.12.011

Sheeja, R.Y. and T. Murugesan, 2002. Studies on biodegradation of phenol using response surface methodology. J. Chem. Technol. Biotechnol., 77: 1219-1230. DOI: $10.1002 /$ jctb.692

Shim, H. and S.T. Yang, 1999. Biodegradation of benzene, toluene, ethylbenzene and o-xylene by a coculture of Pseudomonas putida and Pseudomonas fluorescens immobilized in a fibrous-bed bioreactor. J. Biotechnol., 67: 99-112. DOI: 10.1016/s0168-1656(98)00166-7

Song, J., S. Shin, H.S. Jang, S.J. Hwang, 2012. Kinetics and simulations of substrate interactions during the biodegradation of benzene, toluene, $\mathrm{p}$ xylene and styrene. J. Environ. Sci. Health, 47: 1027-35. DOI: 10.1080/10934529.2012.667320

Sultania, M., J.S.P. Rai and D. Srivastava, 2011. Process modeling, optimization and analysis of esterification reaction of Cashew Nut Shell Liquid (CNSL)-derived epoxy resin using response surface methodology. J. Hazardous Mater., 185: 1198-1204. DOI: 10.1016/j.jhazmat.2010.10.031

Słomińska, M., S. Król and J. Namieśnik, 2012. Removal of BTEX compounds from waste gases; Destruction and recovery techniques. Critical Rev. Environ. Sci. Technol., 43: 1417-1445.

DOI: $10.1080 / 10643389.2011 .647760$

CAAALHAP, 2012. The clean air act amendments of 1990 list of hazardous air pollutants.

Thouchprasitchai, N. A. Luengnaruemitchai and S. Pongstabodee, 2011. Statistical optimization by response surface methodology for water-gas shift reaction in a $\mathrm{H}_{2}$-rich stream over $\mathrm{Cu}-\mathrm{Zn}$-Fe composite-oxide catalysts. J. Taiwan Instit. Chem. Eng., 42: 632-639.

DOI: $10.1016 /$ j.jtice.2010.10.008 
Tokumura, M., R. Nakajima, H.T. Znad and Y. Kawase et al., 2008. Chemical absorption process for degradation of VOC gas using heterogeneous gasliquid photocatalytic oxidation: Toluene degradation by photo-Fenton reaction. Chemosphere, 73: 768775. DOI: 10.1016/j.chemosphere.2008.06.021

Trinh, T.K. and L.S. Kang, 2011. Response surface methodological approach to optimize the coagulation-flocculation process in drinking water treatment. Chem. Eng. Res. Design, 89: 1126-1135. DOI: 10.1016/j.cherd.2010.12.004

Wang, W., T. Yuan, K. Wang, B. Cui and Y. Dai, 2012. Statistical optimization of cellulase production by the brown rot fungi, Fomitopsis palustris and its application in the enzymatic hydrolysis of LHW-pretreated woody biomass. Process Biochem., 47: 2552-2556. DOI: $10.1016 /$ j.procbio.2012.08.004

Yassaa, N., E. Brancaleoni, M. Frattoni and P. Ciccioli, 2006. Isomeric analysis of BTEXs in the atmosphere using $\beta$-cyclodextrin capillary chromatography coupled with thermal desorption and mass spectrometry. Chemosphere, 63: 502-508.

DOI: 10.1016/j.chemosphere.2005.08.010
You, Y., J. Shim, C.H. Cho, M.H. Ryu and P.J. Shea et al., 2013. Biodegradation of BTEX mixture by Pseudomonas putida YNS1 isolated from oilcontaminated soil. J. Basic Microbiol., 53: 469-475. DOI: $10.1002 /$ jobm.201200067

Yuliwati, E., A.F. Ismail, W.J. Lau, B.C. Ng and A. Mataram et al., 2012. Effects of process conditions in submerged ultrafiltration for refinery wastewater treatment: Optimization of operating process by response surface methodology. Desalination, 287: 350-361. DOI: 10.1016/j.desal.2011.08.051

Yus Azila, Y., M.D. Mashitah and S. Bhatia, 2008. Process optimization studies of lead $(\mathrm{Pb}(\mathrm{II}))$ biosorption onto immobilized cells of Pycnoporus sanguineus using response surface methodology. Bioresource Technol., 99: 8549-8552. DOI: $10.1016 /$ j.biortech.2008.03.056

Yüksel, A. and N.Ş. Yeşilçubuk, 2012. Enzymatic production of human milk fat analogues containing stearidonic acid and optimization of reactions by response surface methodology. LWT-Food Sci. Technol., 46: 210-216.

DOI: $10.1016 /$ j.lwt.2011.10.004 